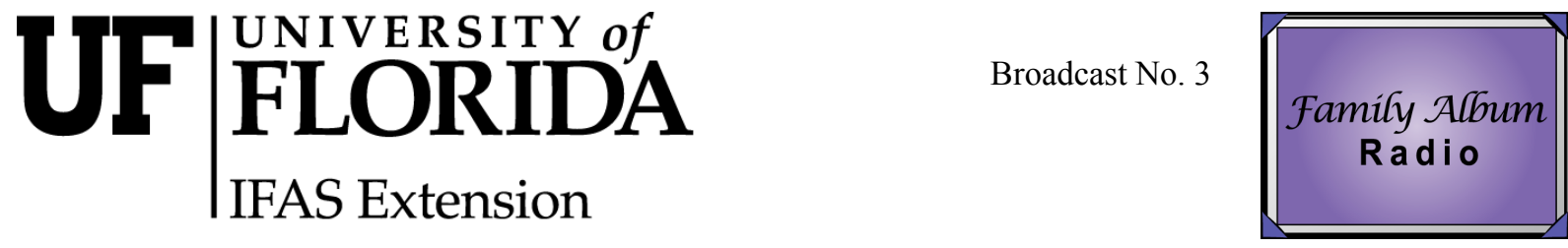

Transcribed from the Family Album Radio Program, a co-production of University of Florida IFAS Extension, the Department of Family, Youth and Community Sciences and of WUFT-FM. If you'd like to learn more, please visit our website at familyalbumradio.org

Listening, learning and living together, it's the science of life.

\section{Marriage and Family Therapy: When To Go/How To Find One $^{1}$}

\section{Donna Davis and Suzanna Smith ${ }^{2}$}

For better or for worse, in sickness and in health ... the words are familiar. Today, when, according to the US Census, approximately $50 \%$ of all marriages end in divorce, there's another phrase that's becoming widely spoken... It's, "I want us to see a counselor."

There are still many people who don't understand or resist counseling - thinking that therapy is for crazy people. Yet, according to one study, at any given time, Marriage and Family therapists are treating 1.8 million people in the U.S. Another myth about the field is that it's just for marriage counseling. You don't have to be with your partner for marriage and family therapy. In fact, couples and families make up less than half of the clients in this field of therapy. Some individuals seek counsel for relationship issues, behavioral issues, pre-marital guidance, or for help in working through divorce. Typically, marriage and family therapy is a short-term, results oriented form of treatment, which maintains a family orientation, considering the family to be the most important influence on an individual. Therapists are trained to circumvent problems, strengthen relationships, and prevent problems from getting out of hand.

1. This document is FAR3000, one of a series of the Family Youth and Community Sciences Department, Florida Cooperative Extension Service, Institute of Food and Agricultural Sciences, University of Florida. Published August 2006. Reviewed by Kate Fogarty. Some scientific language from the original script has been modified to better serve the listener. The script published here represents the actual broadcast as heard on Family Album Radio. Visit the EDIS Web Site at http://edis.ifas.ufl.edu.

2. Donna Davis, Senior Producer, Family Album Radio and Suzanna Smith, Associate Professor, Human Development, Department of Family, Youth and Community Sciences, Cooperative Extension Service, Institute of Food and Agricultural Sciences, University of Florida, Gainesville FL 32611.

The Institute of Food and Agricultural Sciences (IFAS) is an Equal Employment Opportunity - Affirmative Action Employer authorized to provide research, educational information and other services only to individuals and institutions that function without regard to race, creed, color, religion, age, disability, sex, sexual orientation, marital status, national origin, political opinions or affiliations. For information on obtaining other extension publications, contact your county Cooperative Extension Service office. Florida Cooperative Extension Service / Institute of Food and Agricultural Sciences / University of Florida / Larry R. Arrington, Dean. 
This field of therapy enjoys a pretty good track record. In a report to the American Association for Marriage and Family Therapy Research and Education Foundation Doherty and Simmons, of the University of Minnesota, found that $98 \%$ of the marriage and family therapy clients they surveyed rated services as good or excellent, 97\% got the kind of help they were looking for, and $98 \%$ indicated that they felt they had been helped in dealing more effectively with problems.

More information, please visit our website at www.familyalbumradio.org

\section{To listen to the radio broadcast:}

http://radiosource.net/radio_stories/226.wav

http://radiosource.net/radio stories/226.mp3

\section{Reference}

A Consumer's Guide to Marriage and Family Therapy, American Association for Marriage and Family Therapy. Retrieved May 2006 from http://www.amft.org 